\title{
A review of recent advances biomedical implants and their application
}

\author{
K. Prem Ananth ${ }^{1,2 *}$, Jinxing Sun ${ }^{1,2}$, Jiaming Bai ${ }^{1,2 \star}$ \\ ${ }^{I}$ Shenzhen Key Laboratory for Additive Manufacturing of High-performance Materials \\ ${ }^{2}$ Department of Mechanical and Energy Engineering, Southern University of Science and Technology, Shenzhen, \\ 518055, China
}

*Corresponding author

DOI: $10.5185 / \mathrm{amp} .2018 / 1428$

www.vbripress.com/amp

\begin{abstract}
Suitable choice of the biomedical implant biomaterial is a vital aspect for extensive term success of implants. A special review of different types of biomaterials and their primary applications is presented. Still one can name some of the furthermost appropriate features of Biomaterials Science and Technology that make the field so pretty. This article creates a determination to review a number of dental biomaterials which were used in the historical and as well as the most recent material recycled nowadays. Copyright @ 2018 VBRI Press.
\end{abstract}

Keywords: Biomaterials, orthopedic, surface modification, corrosion protection, hydroxyapatite.

\section{Introduction}

A biomaterial can be defined as any material used to make devices to replace a part or a function of the body in a safe, reliable, economic and physiologically acceptable manner. The devices made from biomaterials are called prostheses. According to this definition a prosthesis is a device that "replaces, in part or in whole, the function of one of the organs of the body" [1]. The field of biomaterials is not new and as early as 4000 years back the Egyptians and Romans have used linen for sutures, gold and iron for dental applications and wood for toe replacement but with very little awareness about the problem of corrosion [2].

During the 1960s and 1970s, first generation of materials was especially developed for use inside the human body. These developments became a basis in the field of biomaterials [3]. In the early days, all kinds of natural materials such as wood, glue and rubber, tissues from living forms and manufactured materials such as iron, gold, zinc and glass were used as biomaterials [4]. The general usage of biomedical implant application is shown in (Fig. 1)

Costs for implantable medical devices (IMDs) were estimated to have reached USD 80 billion in 2007, and orthopaedic implant costs alone were expected to grow at a rate of $9.8 \%$ annually, reaching USD 23 billion by 2012 [5]. A recent study of 31 hospitals by the US Government Accountability Office (GAO) found expenditures for procedures involving the use of IMDs increased from USD 16.1 billion to USD 19.8 billion over a 5-year period from 2004 to 2009 [6]. The Brazil market for biomaterials is expected to reach $\$ 1.7$ billion in 2015 from $\$ 550.2$ million in 2008 with a CAGR of $19.5 \%$ from 2010 to 2015 . In 2009, the orthopaedic biomaterial market recorded revenues of $\$ 236.5$ million or $37.5 \%$ of the total biomaterial products market [7]. Today, the field of biomaterial sciences combines various areas of knowledge from medicine and biology to physics and engineering to improve human health by developing biomaterials and biomedical devices. This work would be helpful to the biomedical industry for further usage of such wonderful materials.

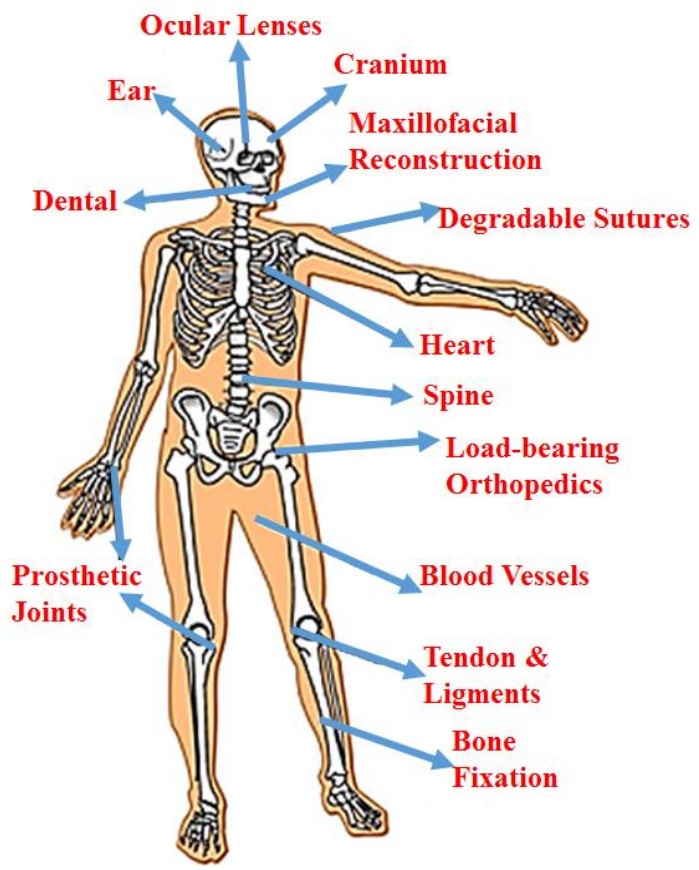

Fig. 1. The general usage of biomedical implant application. 


\section{Classification of biomaterials}

When a synthetic material is placed within the human body, tissue reacts towards the implant in a variety of ways depending on the material type. According to the surgical uses, biomaterials can be classified into four types.

1. Metallic biomaterials

2. Ceramic biomaterials

3. Polymeric biomaterials

4. Composite biomaterials

\section{Metallic Biomaterials}

Metals have been used exclusively for load bearing implants, such as hip and knee prostheses and fracture fixation wires, pins, screws and plates.

The most frequently used metallic systems in the body are:

(a) Iron-Base Alloys of the 316L Stainless Steel

(b) Titanium and Titanium-Base Alloys, such as Ti-6\% Al-4\% V, and commercially pure $>98.9 \%$ $\mathrm{Ti}-\mathrm{Ni}(55 \% \mathrm{Ni}$ and $45 \% \mathrm{Ti})$

(c) Cobalt Base Alloys of Four Types

$\mathrm{Cr}(27-30 \%)$, Mo (5-7\%), Ni (2-5\%)

Cr (19-21\%), Ni (9-11\%), W (14-16\%)

$\mathrm{Cr}(18-22 \%), \mathrm{Fe}(4-6 \%), \mathrm{Ni}(15-25 \%), \mathrm{W}(3-4 \%)$

$\mathrm{Cr}(19-20 \%)$, Mo (9-10\%), Ni (33-37\%)

Metals have biomechanical properties which made them suitable as an implant material. Besides these properties, metals are also easy to process and have good finish. On the other hand, prosthetic components of the implants are still made from gold alloys, stainless steel, cobalt-chromium and nickel-chromium alloys [8]. In the midst of the metallic implants, 316L SS alloy is one of the best performing candidates due to its commendable mechanical properties, low cytotoxicity, valuable corrosion resistance and excellent biocompatibility [9]. Stainless steel was first used successfully as an important material in the surgical field. Stainless steel is the generic name for a number of different steels used primarily because of their resistance to a wide range of corrosive agents $[\mathbf{1 0 , 1 1 ]}$.

\section{Ceramic biomaterials}

Ceramics are another class of materials which have high biocompatibility and enhanced corrosion resistance. They are extensively used for total hip replacement, heart valves, dental implants restorations, bone fillers and scaffolds for tissue engineering. But they are brittle, have high elastic modulus and can fracture as they possess low plasticity [12]. They can be categorized according to the tissue response as:

1. Bioactive : Bioglass/Glass ceramic

2. Bioresorbable: Calcium Phosphate (Hydroxyapatite, Tri calcium Phosphate etc.)

3. Bioinert : Alumina, Zirconia and Carbon
Calcium phosphate ceramics display nontoxic behaviour to tissues, bioresorption and osteoinductive property. Subsequently ceramic/ceramic, ceramic/metal, ceramic/polymer composites include the diverse solid particle stiffeners, they are the prime prerequisite materials for implant applications [13].

\section{Polymeric materials}

The polymeric systems include acrylics, polyamides, polyesters, polyethylene, polysiloxanes, polyurethane and a number of reprocessed biological materials. Polymers are the promising materials for biomedical applications such as cardiovascular devices, replacement and proliferation of various soft tissues [14]. The mandatory properties of polymeric biomaterials are similar to other biomaterials that is biocompatibility, sterilizability, adequate mechanical, physical properties and manufacturability [15]. Polymers (Ultra high molecular weight polyethylene (UHMWPE), Polyurethane (PE), Polyurethane (PU), Polytetrafuoroethylene (PTFE), Polyacetal (PA), Polymethylmethacrylate (PMMA), Polyethylene Terepthalate (PET), Silicone Rubber (SR), Polyetheretherketone (PEEK), Poly (lactic acid) (PLA) and Polysulfone (PS)) have been investigated as biomaterials [16].

\section{Composite biomaterials}

Composite is a material which consist of two or more metal, polymer or ceramic structures that are separated by an interface. Biocomposites are composite materials composed of biodegradable matrix and biodegradable natural fibres as reinforcement [17]. Composite materials have been extensively used in dentistry and prosthesis, designers are now incorporating these materials into a variety of applications. Typically, a matrix of ultrahighmolecular-weight polyethylene (UHMWPE) is reinforced with carbon fibers [18]. Ceramics are generally stiff and brittle materials, polymers are recognized to be flexible and show low mechanical strength and stiffness. Composites aim to combine the properties of both materials for medical applications [19, 20]. The general advantage and disadvantages of metal, ceramic, polymer and composite materials are shown in Table $\mathbf{1}$.

\section{Requirement of biomedical implant}

The essential requirement for the choice of the biomaterial is its acceptability by the human body. The implanted material should not cause any adverse effects like allergy, inflammation and toxicity either immediately after surgery or under post-operative conditions [21]. Normally, four types of response affect the musculo-skeletal system.

* If the material is toxic, the surrounding tissue dies

* The material is nontoxic and biologically inactive (nearly inert), a fibrous tissue of variable thickness forms 
* If the material is nontoxic and biologically active (bioactive), an interfacial bond forms

* If the material is nontoxic and dissolves, the surrounding tissue replaces it.

Table 1. Advantage and disadvantages of metal, ceramic, polymer and composite materials.

\begin{tabular}{|c|c|c|c|c|}
\hline Materials & $\begin{array}{c}\text { Advant } \\
\text { ages }\end{array}$ & $\begin{array}{c}\text { Disadvant } \\
\text { ages }\end{array}$ & Examples & $\begin{array}{c}\text { Implant } \\
\text { images }\end{array}$ \\
\hline $\begin{array}{l}\text { Metals } \\
\text { (Ti and its } \\
\text { alloys Co- } \\
\text { Cr alloys, } \\
\text { Stainless } \\
\text { Steels) }\end{array}$ & $\begin{array}{l}\text { Strong } \\
\text { Tough } \\
\text { Ductile }\end{array}$ & $\begin{array}{l}\text { May } \\
\text { corrode, } \\
\text { Dense, } \\
\text { Difficult } \\
\text { to make }\end{array}$ & $\begin{array}{l}\text { Joint } \\
\text { replacement, } \\
\text { Bone plates } \\
\text { and Screws, } \\
\text { Dental root } \\
\text { Implant, }\end{array}$ & \\
\hline $\begin{array}{l}\text { Ceramics } \\
\text { (Aluminum } \\
\text { Oxide, } \\
\text { calcium } \\
\text { phosphates, } \\
\text { including } \\
\text { hydroxyapa } \\
\text { tite carbon) }\end{array}$ & $\begin{array}{l}\text { Very } \\
\text { biocompa } \\
\text { tible Inert } \\
\text { strong in } \\
\text { compres } \\
\text { sion }\end{array}$ & $\begin{array}{l}\text { Difficult } \\
\text { to make, } \\
\text { Brittle, } \\
\text { Not } \\
\text { resilient }\end{array}$ & $\begin{array}{l}\text { Dental coating } \\
\text { Orthopedic } \\
\text { implants } \\
\text { Femoral head } \\
\text { of hip }\end{array}$ & \\
\hline $\begin{array}{l}\text { Polymers } \\
\text { (nylon, } \\
\text { silicon } \\
\text { Rubber, } \\
\text { polyester, } \\
\text { PTFE, etc.) }\end{array}$ & $\begin{array}{l}\text { Resilient } \\
\text { Easy to } \\
\text { Fabricate }\end{array}$ & $\begin{array}{l}\text { Not } \\
\text { strong, } \\
\text { Deforms } \\
\text { with time, } \\
\text { May } \\
\text { degrade }\end{array}$ & $\begin{array}{l}\text { Blood vessels, } \\
\text { Sutures, ear, } \\
\text { nose, Soft } \\
\text { tissues }\end{array}$ & \\
\hline $\begin{array}{l}\text { Composites } \\
\text { (Carbon- } \\
\text { Carbon, } \\
\text { Wire or } \\
\text { Fiber } \\
\text { reinforced } \\
\text { Bone } \\
\text { cement) }\end{array}$ & $\begin{array}{l}\text { Compres } \\
\text { sion } \\
\text { strong }\end{array}$ & $\begin{array}{l}\text { Difficult } \\
\text { to make }\end{array}$ & $\begin{array}{l}\text { Joint implants } \\
\text { Heart valves }\end{array}$ & \\
\hline
\end{tabular}

A biomaterial used for implant should possess some important properties in order to achieve long-term usage in the body without rejection. The overall requirement of biomedical implant shown in (Fig. 2).

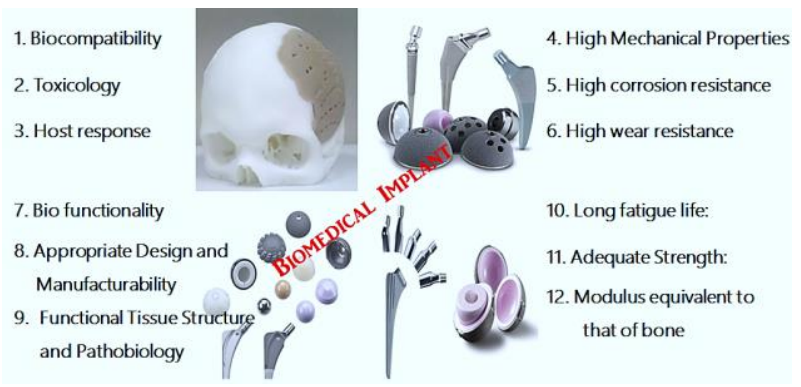

Fig. 2. Requirement of biomedical implant.

Generally, any orthopedic implants should have low porosity, strong cohesive strength, good adhesion to the substrate, a high degree of crystallinity, and high chemical and phase stability [22]. The general requirements concerning the properties of $\mathrm{CaP}$ coatings that should provide a stable long-term effect are summarized in Table 2 [23, 24].
Table 2. Shows the Family of Calcium Phosphates Materials.

\begin{tabular}{|c|c|c|c|c|c|}
\hline $\begin{array}{l}\mathrm{Ca} / \mathrm{P} \\
\text { ratio }\end{array}$ & Compound & Formula & Acronym & $\begin{array}{l}\text { Space } \\
\text { group }\end{array}$ & $\begin{array}{c}\text { Density } \\
\mathrm{g} / \mathrm{cm}^{3}\end{array}$ \\
\hline 0.5 & $\begin{array}{l}\text { Monocalcium } \\
\text { phosphate } \\
\text { monohydrate }\end{array}$ & $\begin{array}{l}\mathrm{Ca}\left(\mathrm{H}_{2} \mathrm{PO}_{4}\right)_{2} . \\
\mathrm{H}_{2} \mathrm{O}\end{array}$ & МCPM & Triclinic $P \overline{1}$ & 2.23 \\
\hline 0.5 & $\begin{array}{l}\text { Monocalcium } \\
\text { phosphate } \\
\text { anhydrous }\end{array}$ & $\mathrm{Ca}\left(\mathrm{H}_{2} \mathrm{PO}_{4}\right)_{2}$ & $\begin{array}{l}\text { MCPA or } \\
\text { MCP }\end{array}$ & Triclinic $P \overline{1}$ & 2.58 \\
\hline 1.0 & $\begin{array}{l}\text { Dicalcium } \\
\text { phosphate } \\
\text { dihydrate }\end{array}$ & $\mathrm{CaHPO}_{4} \cdot 2 \mathrm{H}_{2} \mathrm{O}$ & DCPD & $\begin{array}{l}\text { Monoclinic } \\
I a\end{array}$ & 2.38 \\
\hline 1.0 & $\begin{array}{l}\text { Dicalcium } \\
\text { phosphate } \\
\text { dehydrate } \\
\text { anhydrous }\end{array}$ & $\mathrm{CaHPO}_{4}$ & $\begin{array}{l}\text { DCPA or } \\
\text { DCP }\end{array}$ & Triclinic $P \overline{1}$ & 2.89 \\
\hline 1.33 & $\begin{array}{l}\text { Octacalcium } \\
\text { phosphate }\end{array}$ & $\begin{array}{l}\mathrm{Ca}_{8} \\
\left(\mathrm{HPO}_{4}\right)_{2}\left(\mathrm{PO}_{4}\right) \\
5 \mathrm{H}_{2} \mathrm{O}\end{array}$ & $\mathrm{OCP}$ & Triclinic $P \overline{1}$ & 2.61 \\
\hline 1.5 & $\begin{array}{l}\alpha \text {-Tricalcium } \\
\text { phosphate } \\
(\alpha-\text { TCP })\end{array}$ & $\alpha-\mathrm{Ca}_{3}\left(\mathrm{PO}_{4}\right)_{2}$ & $\alpha-\mathrm{TCP}$ & $\begin{array}{l}\text { Monoclinic } \\
\mathrm{P} 2_{1} / \mathrm{a}\end{array}$ & 2.86 \\
\hline 1.5 & $\begin{array}{l}\beta \text {-Tricalcium } \\
\text { phosphate } \\
(\beta-T C P)\end{array}$ & $\beta-\mathrm{Ca}_{3}\left(\mathrm{PO}_{4}\right)_{2}$ & $\beta-\mathrm{TCP}$ & $\begin{array}{l}\text { Rhombohed } \\
\text { ral R3cH }\end{array}$ & 3.08 \\
\hline $\begin{array}{l}1.2- \\
2.2\end{array}$ & $\begin{array}{l}\text { Amorphous } \\
\text { calcium } \\
\text { phosphates }\end{array}$ & $\begin{array}{l}\left.\mathrm{Ca}_{x} \mathrm{H}_{\mathrm{y}} \mathrm{PO}_{4}\right)_{z .} \mathrm{n} \\
\mathrm{H}_{2} \mathrm{O}, \mathrm{n}=3-4.5 ; \\
15-20 \% \mathrm{H}_{2} \mathrm{O}\end{array}$ & $\mathrm{ACP}$ & - & - \\
\hline $\begin{array}{l}1.5- \\
1.67\end{array}$ & $\begin{array}{l}\text { Calcium- } \\
\text { deficient } \\
\text { hydroxyapatite }\end{array}$ & $\begin{array}{l}\mathrm{Ca}_{10-\mathrm{x}}\left(\mathrm{HPO}_{4}\right)_{\mathrm{x}} \\
\left(\mathrm{PO}_{4}\right)_{6-\mathrm{x}}(\mathrm{OH})_{2-\mathrm{x}} \\
(0<\mathrm{x}<1)\end{array}$ & CDHA & - & - \\
\hline 1.67 & Hydroxyapatite & $\begin{array}{l}\mathrm{Ca}_{10}\left(\mathrm{PO}_{4}\right)_{6 .} . \\
(\mathrm{OH})_{2}\end{array}$ & $\begin{array}{l}\text { HA or HAp } \\
\text { or OHAp }\end{array}$ & $\begin{array}{l}\text { Monoclinic } \\
P 2_{l} / b \\
\text { Hexagonal } \\
P 6_{3} / 3\end{array}$ & 3.16 \\
\hline 1.67 & Fluorapatite & $\mathrm{Ca}_{10}\left(\mathrm{PO}_{4}\right)_{6} \cdot \mathrm{F}_{2}$ & FA or FAp & $\begin{array}{l}\text { Hexagonal } \\
\mathrm{P}_{3} / 3\end{array}$ & 3.20 \\
\hline 1.67 & Oxyapatite & $\mathrm{Ca}_{10}\left(\mathrm{PO}_{4}\right)_{6 .} \mathrm{O}$ & $\mathrm{OA}$ or $\mathrm{OAp}$ & $\begin{array}{l}\text { Hexagonal } \\
\text { P6 }\end{array}$ & 3.2 \\
\hline 2.0 & $\begin{array}{l}\text { Tetracalcium } \\
\text { Phosphate }\end{array}$ & $\mathrm{Ca}_{4}\left(\mathrm{PO}_{4}\right)_{2} . \mathrm{O}$ & TTCP & $\begin{array}{l}\text { Monoclinic } \\
\mathrm{P} 2_{1}\end{array}$ & 3.05 \\
\hline
\end{tabular}

\section{Material introduction}

\section{Calcium phosphates}

Calcium phosphates include a family of exceptionally biocompatible solid materials that can be used for a multiplicity of grafting and tissue amplification processes. Their physical properties can range from hard and insoluble to soft, friable and soluble. The properties can be controlled by many factors that include setting the calcium to phosphorous ratio, the presence of traces of other biocompatible metal ions, the control of density and the inclusion of porosity [25].

\section{Hydroxyapatite}

Among the calcium phosphate bioceramics, Hydroxyapatite is the most advanced biomaterial for the repair and reconstruction of bone tissue defects. It has all the characteristic features of biomaterials, such as biocompatibility, bioactive, osteoconductive, non-toxic, non-inflammatory and non-immunogenic properties. Hydroxyapatite (HAp) and $\beta$-tricalcium phosphate $(\beta$-TCP) are extensively used as potential bioceramics for both dental and orthopaedic applications due to their close chemical resemblance with the inorganic component of bone and tooth mineral [26]. HAp is 
more effective as bone replacing materials in orthopaedic surgery because of its inherent ability to bond with the hard tissue. [27]. Fig. 3 shows the (a) Crystal structure of hydroxyapatite after projected perpendicular to c-axis. (b) Crystal structure of hydroxyapatite after projected on (001) [28]. HAp has two crystal forms i) monoclinic, space group $\mathrm{P} 21 / \mathrm{b}$, and ii) hexagonal, space group $\mathrm{P}_{3} / \mathrm{m}$. Only the hexagonal phase is of practical significance because the monoclinic form is weakened by the presence of even small amounts of foreign ions. Hexagonal (space group $\mathrm{P} 63 / \mathrm{m}), \mathrm{a}=\mathrm{b}=9.432 \AA, \mathrm{c}=6.881 \AA, \alpha=\beta=90^{\circ}$, and $\gamma=120$ Hexagonal stack of $\mathrm{PO}_{4}{ }^{3-}$ groups with two kinds of tunnels. The first kind of tunnel is occupied by $\mathrm{Ca}^{2+}$ ions.

The second one is lined by oxygen, other calcium ions and $\mathrm{OH}^{-}$ions. [29].

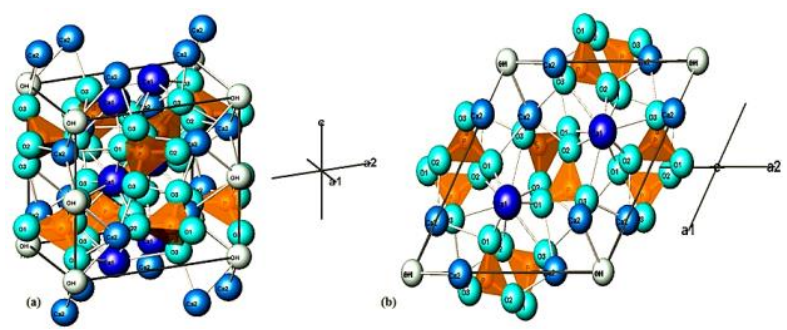

Fig. 3. (a) Crystal structure of hydroxyapatite after projected perpendicular to c-axis. (b) Crystal structure of hydroxyapatite after projected on (001).

\section{Ionic substitution of hydroxyapatite}

Bone is a mixture of inorganic calcium phosphate (69\%) component and organic component that mainly consists of collagen $(20 \%)$ and water $(9 \%)$. Natural bone composed of calcium phosphate mineral, which is in apatite phase with trace elements such as bivalent cation $\mathrm{Zn}^{2+}, \mathrm{Ca}^{2+}, \mathrm{Sr}^{2+}, \mathrm{Ba}^{2+}, \mathrm{Mn}^{2+} \mathrm{Mg}^{2+}, \mathrm{Cd}^{2+}$ and $\mathrm{Pb}^{2+}$. Monovalent cation/anion $\mathrm{Na}^{+}, \mathrm{K}^{+}, \mathrm{OH}^{-}, \mathrm{F}^{-}, \mathrm{Cl}^{-}$and $\mathrm{Br}^{-}$ and trivalent cation /anion $\mathrm{Al}^{3+}, \mathrm{PO}_{4}{ }^{3-}, \mathrm{VO}_{4}{ }^{3}$ and $\mathrm{SO}_{4}{ }^{3-}$ embedded in it play a very crucial role in the biological and mechanical performance of the bone [30]. Presently synthetic HAp structure is also flexible on acceptability of trace elements [31]. It is also well known that the mineral component of bone is similar to HAp but contains other ions as impurities in composition as indicated in Table 3.

Table 3. Bone composition.

\begin{tabular}{|c|c|c|c|c|}
\hline Composition (wt\%) & Enamel & Dentin & Bone & HAp \\
\hline Calcium & 34.8 & 36.5 & 35.1 & 39.6 \\
\hline Phosphorus & 17.7 & 16.9 & 15.2 & 18.5 \\
\hline $\mathrm{Ca} / \mathrm{P}$ (molar ratio) 67 & 1.63 & 1.61 & 1.71 & 1.67 \\
\hline Sodium & 0.50 & 0.60 & 0.9 & - \\
\hline Magnesium & 0.44 & 1.23 & 0.72 & - \\
\hline Potassium & 0.08 & 0.05 & 0.03 & - \\
\hline Carbonate (as $\mathrm{CO}_{3}{ }^{2-}$ ) & 3.5 & 5.6 & 7.4 & - \\
\hline Fluoride & 0.01 & 0.06 & 0.03 & - \\
\hline Chloride & 0.30 & 0.01 & 0.13 & - \\
\hline \multicolumn{5}{|l|}{$\begin{array}{l}\text { Crystallographic } \\
\text { properties: Lattice } \\
\text { parameters }( \pm 0.003 \AA)\end{array}$} \\
\hline a-axis $(\AA)$ & 9.441 & 9.421 & 9.41 & 9.430 \\
\hline C-axis $(\stackrel{\AA}{\AA})$ & 6.880 & 6.887 & 6.89 & 6.891 \\
\hline
\end{tabular}

\section{Role of trace elements}

Silica Osteoblast proliferation, differentiation, collagen production, cell matrix attachment, decreasing the resorption rate and increasing the alkaline phosphates activity which is an indicator of bone remodelling process [32].

Strontium Improves the replication of preosteoblastic cells, stimulates bone formation and increases mechanical resistance of bones [33]

Sodium Major trace element next to Ca \& P (Role in cell adhesion, bone metabolism and resorption process [34]

Fluorine Provides higher chemical and thermal stability, suppress dental caries [35] stimulate the proliferation of bone cells [36]

Magnesium Qualitative effect on the bone matrix that determines bone fragility. Its depletion adversely affects all stages of skeletal metabolism, causing cessation of bone growth and decrease of osteoblastic activities [37].

Potassium Excess level at extra cellular matrix of the bone that has an active role on the apatite biomineralization [38].

Chlorine Acidic environment on bone surface that activates osteoclasts in the bone resorption process $[39,40]$. Thus incorporation of chlorine in apatites may be vital in the development of low $\mathrm{pH}$ to solubilize the alkaline salts of bone mineral and to digest the organic matrix by acid hydrolases which osteoclasts secrete

Manganese Improves the mechanical properties controlled cell interactions with the extra cellular matrix and activate cellular adhesion [41]

\section{Structure and properties of $316 \mathrm{~L}$ SS}

Stainless steel alloys have been used for biomedical applications since the 1920s [42]. In the past few decades, surgical grade 316L SS has become the greatest favoured choice in implant material because of their excellent mechanical properties, respectable process ability, good biocompatibility, low cost and acceptable corrosion resistance[43]. Fig. 4 shows the common 316L SS implant usage in human body. Stainless steel is the generic name for a number of different steels used primarily because of their resistance to a wide range of corrosive agents [44].

316L SS alloy was used as the metal substrate and the elemental composition of it is (in wt \%) C- 0.0222 , Si- $0.551, \mathrm{Mn}-1.67, \mathrm{P}-0.023, \mathrm{~S}-0.0045, \mathrm{Cr}-17.05$, Ni- 11.65, Mo- 2.53, Co- 0.136, Cu- 0.231, Ti- 0.0052, $\mathrm{V}-0.0783$, N- 0.0659 and the rest Fe) [45]. The 
mechanical properties of metallic biomaterials are listed in Table 4 [46].

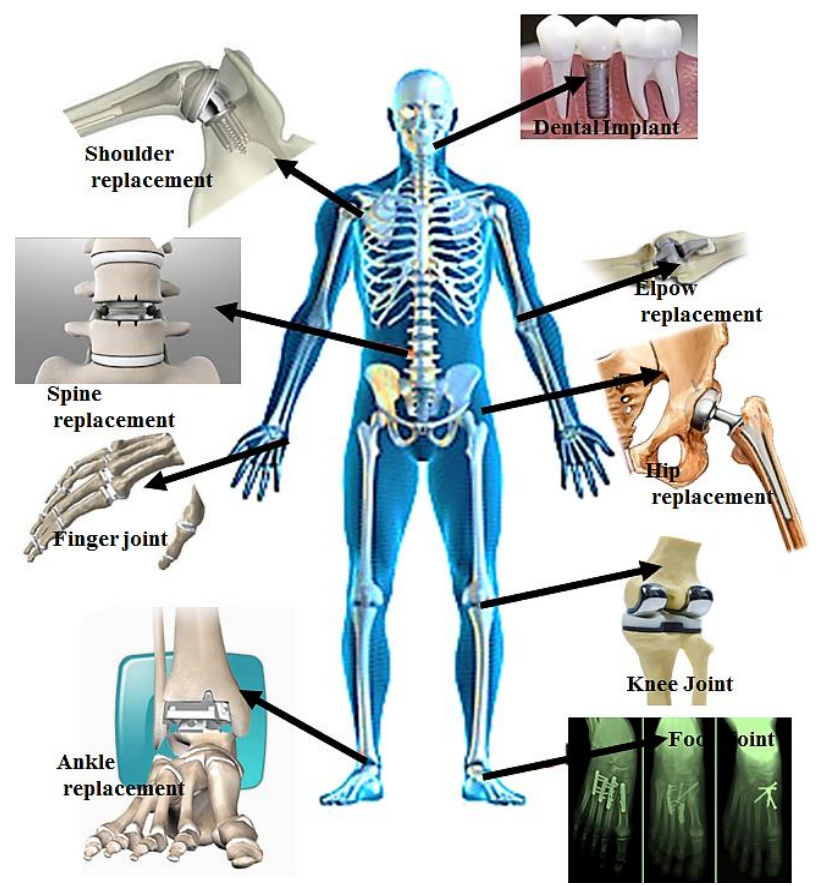

Fig. 4. The Common 316L SS Implant Usage in Human Body.

Table 4. Mechanical properties of metallic biomaterials.

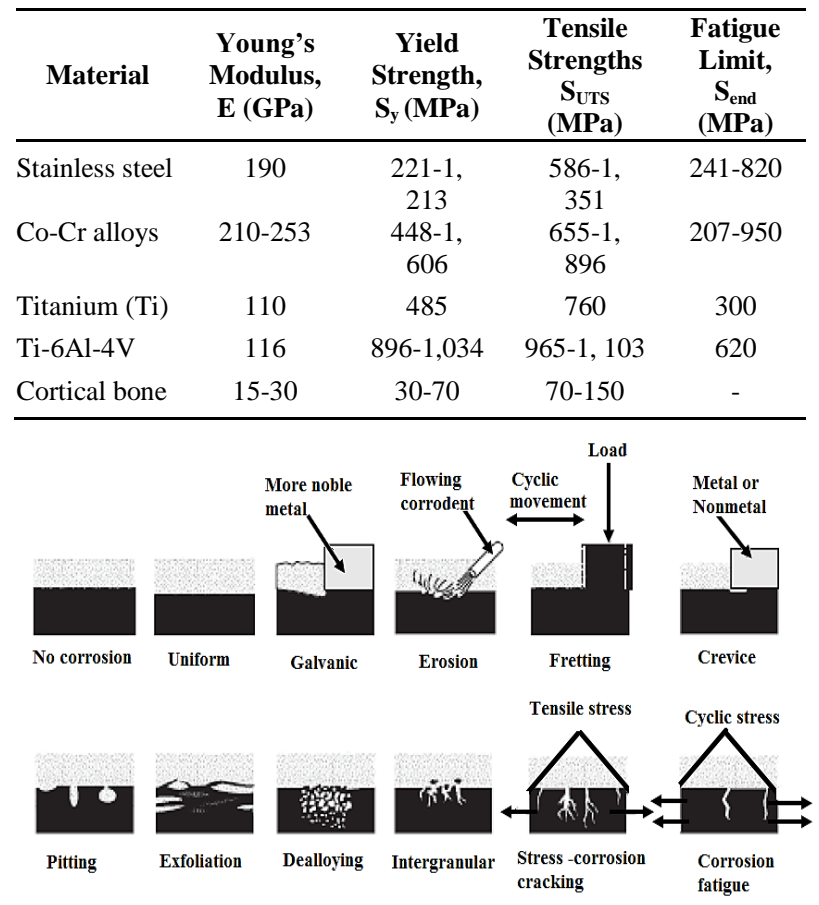

Fig. 5. Different forms of corrosion behaviour.

\section{Corrosion of 316L SS in biological environment}

Corrosion is defined as the deterioration of a material due to the reaction with the surrounding environment. The degradation of the material can be caused by chemical, electrochemical or physical reactions, or by a combination of them [47]. The gradual degradation of materials by electrochemical attack is of great concern particularly when a metallic implant is placed in the hostile electrolytic environment of the human body. When the implant close contact with body fluids, in the electrochemical perspective, the implants face severe corrosion environment which includes blood and other constituents of the body fluid which encompass several constituents like water, sodium, chlorine, proteins, plasma, amino acids along with mucin in the case of saliva [48]. Different forms of corrosion behaviour are as shown in Fig. 5.

When a metal specimen is immersed in a corrosive medium, both reduction and oxidation processes occur on its surface. The general corrosion reaction mechanism is shown in Fig. 6. For the occurrence of electrochemical reactions, four components must be present and active, they are anode, cathode, electron path and electrolyte.
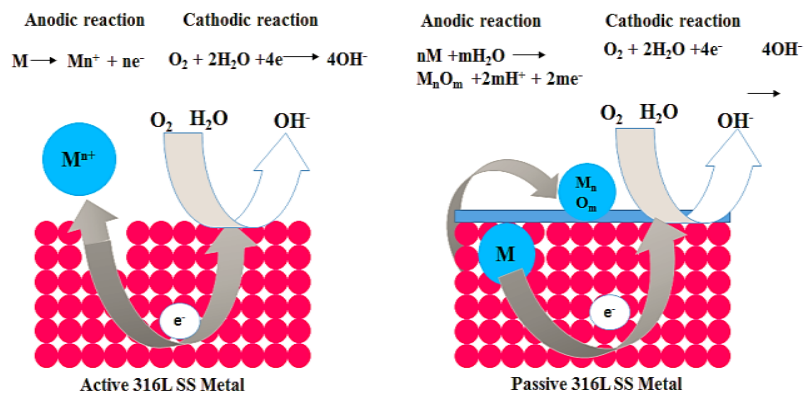

Fig. 6. The general corrosion reaction mechanism.

\section{Literature review (Corrosion Prevention and Control)}

Surface treatment or surface modification is considered as one most important concern on recent developments in metallic biomaterials for corrosion control [49]. Corrosion is one of the foremost problems with metallic implants, specifically in the case of prolonged implantation in human tissues. Since these devices will be in close interaction with body fluids, the release of metallic ions such as iron, chromium and nickel to the neighboring tissue can pose severe carcinogenic problems and can also cause harsh allergic reactions [50]. Development of non-toxic, biocompatible, stronger and cheaper implant materials is one of the utmost significant research areas in the field of orthopedic and dental applications [51]. Hence, in order to overcome the adverse reactions of $316 \mathrm{~L}$ SS in the human body and to increase the lifetime of orthopaedic devices after implantation, surface treatment of metal is often required. Several surface modification techniques have been applied to improve the corrosion resistance of the 316L SS in physiological fluids [52]. Many coating techniques such as plasma spraying, dip coating, sputter coating, bio mimetic coating, electrophoretic, plasma ion laser melting (LSM), laser alloying (LSA), laser nitration, ion implantation and physical vapour deposition (PVD) are investigated [5359]. Table 5 shows the advantages and disadvantages of the various techniques for coating implants with HAp [60]. 
Table 5. Advantages and disadvantages of the various techniques for HAp coatings.

\begin{tabular}{|c|c|c|}
\hline Technique & Advantages & Disadvantages \\
\hline $\begin{array}{l}\text { Pulsed } \\
\text { laser } \\
\text { deposition }\end{array}$ & $\begin{array}{l}\text { Coating with crystalline } \\
\text { and amorphous phases; } \\
\text { dense and porous } \\
\text { coating }\end{array}$ & Line of sight technique \\
\hline $\begin{array}{l}\text { Plasma } \\
\text { spraying }\end{array}$ & $\begin{array}{l}\text { High deposition rates; } \\
\text { low cost }\end{array}$ & $\begin{array}{l}\text { Line of sight technique; } \\
\text { high temperatures induce } \\
\text { decomposition; rapid } \\
\text { cooling produces } \\
\text { amorphous coatings; } \\
\text { relatively thick coatings }\end{array}$ \\
\hline $\begin{array}{l}\text { Sputter } \\
\text { coating }\end{array}$ & $\begin{array}{l}\text { Uniform coating } \\
\text { thickness on flat } \\
\text { substrates; dense } \\
\text { coating }\end{array}$ & $\begin{array}{l}\text { Line of sight technique; } \\
\text { expensive time } \\
\text { consuming; produces } \\
\text { amorphous coatings }\end{array}$ \\
\hline Sol-gel & $\begin{array}{l}\text { Can coat complex shapes; } \\
\text { Low processing } \\
\text { temperatures; relatively } \\
\text { cheap as coatings are very } \\
\text { thin }\end{array}$ & $\begin{array}{l}\text { Some processes require } \\
\text { controlled atmosphere } \\
\text { processing; expensive raw } \\
\text { materials }\end{array}$ \\
\hline Dip coating & $\begin{array}{l}\text { Inexpensive; coatings } \\
\text { applied quickly; can } \\
\text { coat complex substrates }\end{array}$ & $\begin{array}{l}\text { Requires high sintering } \\
\text { temperatures; thermal } \\
\text { expansion mismatch }\end{array}$ \\
\hline $\begin{array}{l}\text { Dynamic } \\
\text { mixing } \\
\text { method }\end{array}$ & High adhesive strength & $\begin{array}{l}\text { Line of sight technique; } \\
\text { expensive; produces } \\
\text { amorphous coatings }\end{array}$ \\
\hline $\begin{array}{l}\text { Electro- } \\
\text { chemical } \\
\text { deposition }\end{array}$ & $\begin{array}{l}\text { Uniform coating } \\
\text { thickness; Rapid } \\
\text { deposition rates; can } \\
\text { coat complex } \\
\text { substrates; moderate } \\
\text { temperature; low cost }\end{array}$ & $\begin{array}{l}\text { Poor adhesion with } \\
\text { substrate }\end{array}$ \\
\hline $\begin{array}{l}\text { Hot } \\
\text { isostatic } \\
\text { pressing }\end{array}$ & $\begin{array}{l}\text { Produces dense } \\
\text { coatings }\end{array}$ & $\begin{array}{l}\text { Cannot coat complex } \\
\text { substrates; high } \\
\text { temperature required; } \\
\text { thermal expansion } \\
\text { mismatch; elastic property } \\
\text { differences; expensive; } \\
\text { removal/interaction of } \\
\text { encapsulation material }\end{array}$ \\
\hline $\begin{array}{l}\text { Electro- } \\
\text { phoretic } \\
\text { deposition }\end{array}$ & $\begin{array}{l}\text { Uniform coating } \\
\text { thickness; rapid } \\
\text { deposition rates; can } \\
\text { coat complex substrates }\end{array}$ & $\begin{array}{l}\text { Difficult to produce crack- } \\
\text { free coatings; requires } \\
\text { high sintering } \\
\text { temperatures }\end{array}$ \\
\hline $\begin{array}{l}\text { Biomimetic } \\
\text { coating }\end{array}$ & $\begin{array}{l}\text { Low processing } \\
\text { temperatures; can form } \\
\text { bonelike apatite; can } \\
\text { coat complex shapes; } \\
\text { can incorporate bone } \\
\text { growth stimulating } \\
\text { factors }\end{array}$ & $\begin{array}{l}\text { Time consuming; requires } \\
\text { replenishment and a } \\
\text { constant } \mathrm{pH} \text { of simulated } \\
\text { body fluid; poor adhesion } \\
\text { with substrate }\end{array}$ \\
\hline
\end{tabular}

\section{Surface modification of $316 L$ SS for corrosion prevention}

In the following section, a review has been done on different surface modification material piranha treated, poly (\&-caprolactone) (PCL) and Polypyrrole (PPy) as a base layer coating on $316 \mathrm{~L}$ SS substrate by electrodeposition and dip coating technique, with a comparative table for corrosion protection for Implant application.

\section{Acid treated 316L SS}

Surface treated and HAp coated 316L SS can be used as a human body implants inorder to achieve two goals, improvement of corrosion resistance and bone osteointegration. Particularly, acid treated 316L SS enhance the corrosion protection, decrease the release of metallic ions, and prevent tissue damages, inflammation, irritation and desirable histopathological response. The second improvement is in terms of bone osteointegration and bone bonding with the coated implant. Surface treatment of $316 \mathrm{~L}$ SS with $\mathrm{H}_{2} \mathrm{SO}_{4}$ solution is more effective than $\mathrm{HNO}_{3}$ in increasing corrosion resistance [61]. Immersion above $20 \%$ led to about $0.003 \mathrm{~g}$ weight loss of $316 \mathrm{~L}$ SS for $25 \%$ treatment and $0.0034 \mathrm{~g}$ for $30 \%$ treatment. The immersion above $25 \%$ concentration of $\mathrm{H}_{2} \mathrm{SO}_{4}$ can cause rapid dissolution of metal and thus, the optimum concentration for $\mathrm{H}_{2} \mathrm{SO}_{4}$ treatment is $20 \%$ [62].

$316 \mathrm{~L}$ SS treated with various concentration of $\mathrm{H}_{3} \mathrm{PO}_{4}, 40 \%$ acid concentration have recorded $\mathrm{E}_{\mathrm{b}}$ value of $+720 \mathrm{mV}$ and a re-passivation potential of $+330 \mathrm{mV}$. Furthermore, HAp coated on the $40 \% \mathrm{H}_{3} \mathrm{PO}_{4}$ treated $316 \mathrm{~L}$ SS shows a maximum $\mathrm{E}_{\mathrm{b}}$ Value of $+830 \mathrm{mV}$ and re- passivation potential of $+280 \mathrm{mV}$ [63]. Surface treated and HAp coated 316L SS ( $\mathrm{E}_{\text {corr }}=-115 \mathrm{mV}$, I $\mathrm{I}_{\text {Corr }}$ $=56 \mathrm{nA} / \mathrm{cm}$ ) have more corrosion resistance than uncoated 316L SS $\left(E_{\text {Corr }}=-174 \mathrm{mV}, I_{\text {Corr }}=256 \mathrm{nA} / \mathrm{cm}\right)$ [64]. The Acid treatment and bioceramic coatings have been recently considered by a number of researchers for improvement of biomedical applications and offers potential clinical benefits in orthopedic and dental surgery [65].

\section{Poly (E-caprolactone) (PCL) coated steel implant}

Polymer coated metallic implant provide mechanical support and prevent the corrosion or serve as a drug vehicle for controlled release [66]. Many biodegradable polymers such as poly (1-lactic acid) (PLLA), poly ( $\varepsilon$ caprolactone) (PCL) and poly (glycolic acid) (PLGA) have been approved for human clinical uses including small load-bearing bone implants and cardiovascular interventions [67]. Proper biocompatibility should not produce any obvious foreign body reactions, blood coagulation, nor inflammation [68]. Biocompatibility PCL coated metallic implants have been investigated due to corrosion protection controlled biodegradation rate and good cytocompatibility [69]. Ceramic conversion coating and layer-by-layer polymeric coatings such as PLGA, PCL combination reduces immediate and long-term corrosion of the substrate. The coatings also provided improved biocompatibility, cellular adhesion and proliferation in comparison to the uncoated alloy surface [70]. The primary layer of the PCL coating on 316L SS prevent the release of toxic ions thereby enhancing the adhesion strength between the coating and the substrate [71]. In vitro dynamic degradation of pure Mg with PLLA and PCL coatings showed that PCL had better corrosion resistance in modified simulated body fluid solution than PLLA [72]. However PCL coating is an appropriate and alternative material for orthopaedic implants when compared to the existing coating materials [73]. 
Table 6. Some examples of PPy coatings based metal for corrosion protection.

\begin{tabular}{|c|c|c|c|c|}
\hline $\begin{array}{l}\text { Polymer and } \\
\text { Substrate }\end{array}$ & $\begin{array}{l}\text { Deposition } \\
\text { Technique }\end{array}$ & Method of Corrosion Tests & Results & Refer-ence \\
\hline PPy on steel & $\begin{array}{l}\text { Cyclic } \\
\text { voltammetry }\end{array}$ & Tafel polarisation in $1 \mathrm{M} \mathrm{H}_{2} \mathrm{SO}_{4}$ & $\begin{array}{l}\text { The corrosion performance of monolayer PPy coating is } \\
\text { worse than that of bilayer PPy/PANI and PANI/PPy } \\
\text { coating. }\end{array}$ & [81] \\
\hline PPy on steel & $\begin{array}{l}\text { Galvanostatic } \\
\text { deposition }\end{array}$ & $\begin{array}{l}\text { Potentiodynamic polarisation, monitoring } \\
\mathrm{OCP} \text {, and EIS in } 3.5 \% \mathrm{NaCl}\end{array}$ & $\begin{array}{l}\text { PPy coating has worse anticorrosion properties than PPy }+ \\
\mathrm{ZnO} \text { coating with } 10 \mathrm{wt} \% \text { of } \mathrm{ZnO} \text { relative to PPy. }\end{array}$ & [82] \\
\hline $\begin{array}{l}\text { PANI/PPy on } \\
\text { steel }\end{array}$ & $\begin{array}{l}\text { Cyclic } \\
\text { voltammetry }\end{array}$ & $\begin{array}{l}\text { Tafel polarisation in } 0.1 \mathrm{M} \mathrm{HCl} \text { EIS in } 0.5 \mathrm{M} \\
\mathrm{NaCl}, 0.1 \mathrm{M} \quad \mathrm{HCl} \text { Potentiodynamic } \\
\text { polarisation in } 0.5 \mathrm{M} \mathrm{H}_{2} \mathrm{SO}_{4}\end{array}$ & $\begin{array}{l}\text { All corrosion tests show the best performance of PPy } \\
\text { single coating with respect to the single PANI coating, and } \\
\text { PANI/PPy and PPy/PANI bilayer coatings. }\end{array}$ & [83] \\
\hline $\begin{array}{l}\text { PPy-PMo/PPyDoS } \\
\text { on steel }\end{array}$ & $\begin{array}{l}\text { Oxidative } \\
\text { polymerisation }\end{array}$ & Monitoring OCP in $3.5 \% \mathrm{NaCl}$ & $\begin{array}{l}\text { The steel coated by the PPy based bilayer coating is kept } \\
\text { passive for about } 200 \text { hours in } \mathrm{NaCl} \text { environment. }\end{array}$ & [84] \\
\hline $\begin{array}{l}\text { PPy/PNEA on } \\
\text { steel }\end{array}$ & $\begin{array}{l}\text { Cyclic } \\
\text { voltammetry }\end{array}$ & Tafel polarisation in $1 \mathrm{M} \mathrm{H}_{2} \mathrm{SO}_{4}$ & $\begin{array}{l}\text { The bilayer coating is more efficient than PNEA monolayer } \\
\text { coating. }\end{array}$ & [85] \\
\hline $\begin{array}{l}\text { PPy+MMT on } \\
\text { steel }\end{array}$ & Dip coating & Tafel polarisation in $5 \% \mathrm{NaCl}$ & $\begin{array}{l}\text { Increasing the MMT content in PPy from } 0 \text { to } 10 \mathrm{wt} \% \text {, the } \\
\text { corrosion current decreases and the corrosion potential } \\
\text { shifts to nobler potential values. }\end{array}$ & [86] \\
\hline $\begin{array}{l}\text { PPy with epoxy } \\
\text { on steel }\end{array}$ & $\begin{array}{l}\text { Immersion and } \\
\text { solvent } \\
\text { evaporation }\end{array}$ & Immersion in $3.5 \% \mathrm{NaCl}$ & $\begin{array}{l}\text { The epoxy coating containing PPy (with concentration } \\
\text { from } 0.3 \text { to } 1.5 \mathrm{wt} \% \text { ) provides a better corrosion protection } \\
\text { with respect to the unmodified epoxy coating, but a worse } \\
\text { one with respect to PANI coating with epoxy. }\end{array}$ & [87] \\
\hline
\end{tabular}

\section{Polypyrrole (PPy) coated steel implant}

Conductive polymers have been found to be optimistic materials for analytical applications. Polypyrrole (PPy) is one of the most favorable conductive polymers due to its numerous advantages such as relatively easy synthesis, good mechanical stability, and corrosion protection. The first layer of the PPy on 316L SS prevents the release of toxic ions thereby enhancing the adhesion strength between the coating and the substrate [74]. Polypyrrole based corrosion resistant coatings can be prepared either by chemical synthesis or it may be electrochemically deposited on the metal surface. Electrochemical deposition of polypyrrole coatings are reported to be carried out on steel substrates using aqueous media $[\mathbf{7 5}, \mathbf{7 6}]$. PPy coating has also an excellent corrosion resistance due to its high stability, which prevent the electron exchange between the metal and the adsorbed biological species [77].

PPy satisfies passive biocompatibility, since an adverse tissue response is not observed at PPy coated implants with excellent electrical impedance response [78]. Bilayer model, designed for the corrosion protection, includes two important factors: one is stabilization of the passive film on the steel by action of dopant ions in the inner PPy layer and the other is control of ionic perm-selectivity by organic acid ions doped in the outer PPy layer [79]. PPy/Sr-HA bilayer can act as a corrosion resistant coating for improved performance, for a longer duration, cell Ingrowth proliferation and differentiation into the will facilitate tissue regeneration. Thus, the porous Sr-HA coating on PPy coated 316L SS appears to be a potential implant material in tissue engineering applications [80]. Table 6 shows some examples of PPy coatings based metal for corrosion protection.

\section{Conclusion}

The appropriate bioactivity, biocompatible, stronger and inexpensive synthetic materials are essential in the field of orthopedic and dental application.
Furthermore, the substitution of ion in such Silica $(\mathrm{Si})$, Strontium (Sr), Zinc (Zn), Fluorine (F) and Magnesium $(\mathrm{Mg})$ are considered to have great influence on the physical, chemical, and physiological properties of the solid bone and teeth and subsequently on the mineralization, demineralization, and remineralization process. In a nut shell, the surface modification on 316 LSS implants is cell-stimulating, therapeutic interfaces of metallic implants and potential materials for bone repair and regeneration. The successful surface modification coating ever increasing cooperation of individuals with expertise in materials science, biomechanics and cell biologists in order to attain increased functional longevity of the implant in the human body.

\section{Acknowledgement}

The Shenzhen Key Laboratory financially supported this work for Additive Manufacturing of High-performance Materials, Department of Mechanical and Energy Engineering, Southern University of Science and Technology. Grant No. ZDSYS201703031748354

\section{Reference}

1. Hench L.L.; Erthridge, E.C; Biomaterials-An Interfacial Approach., 1982.

2. Noordergraaf, A. (Eds); New York: Academic Press); 4.

3. Williams, D.F; (Eds); Current perspectives on implantable devices. India, 1990.

4. Nitesh, P. R.; Piyush, G.P; Inter. J. Emerg. Tech. and Adv. Eng., 2012, 2, 91.

5. Rea, S.M.; Bonfield, W.; Aust, J; Ceram. Soc., 2004, 40, 43.

6. Burns, L. R.; Housman, M.G.; Booth, R.E.; Koenig, A; Health Care Manage Rev., 2009, 34, 2

7. US Government Accountability Office. GAO-12-126. 2012. November 29 http://www.gao.gov/assets/590/587688.pdf.

8. Brazil Biomaterials Market http://www.marketsandmarkets.com/knowledge-processoutsourcing-services.asp

9. Sykaras, N.; Iacopino, A.M.; Marker, V.A.; Triplett, R.G.; Woody. R.D; Int. J. Oral Maxillo. Fac. Implants., 2000, 15, 675.

10. Yunchang, X.; Kaifu, H.; Hu, T.; Guoyi, T.; Paul, K.C; Acta. Biomater., 2008, 4, 2008. 
11. Navarro, M.; Michiardi, A.; Castano, O.; Planell. J.A.; Soc, J. R; Interface., 2008, 5, 1137.

12. Alvarado, J.; Maldonado, R.; Marxuach, J.; Otero, R; Applications of Engineering Mechanics in Medicine, GED University of Puerto Rico Mayaguez. 2003.

13. Slonaker, M.; Goswami, T; Mater. Des., 2004, 25, 395.

14. Thamaraiselvi, T.V.; Rajeswari. S.; Artif, T.B; Organs., 2004, $18,9$.

15. Kohn J.; Langer. R.; atner, B.D.; Homan, A.S.; Shoen, F.J.; Lemons, J.E; Academic Press, San Diego, 1996, 64.

16. Hai Bang, L.; Gilson, K.; Jin L.H. (Eds.); Polymeric Biomaterials book. Biomedical Engineering Fundamentals, 2006, 40, 1.

17. Hench. L.L; J. American. Cera. Soc., 1991, 74, 1487.

18. P. K. Mallick. (Eds.); Composites Engineering Handbook. New York: Marcel Dekker, 1997.

19. Carr, B.C.; Goswami, T; Mater. Des., 2009, 30, 398.

20. Williams, D.F; J. Mat. Sci., 1987, 22, 3421.

21. Chandra, R.; Rustgi. R; Progress in Polymer Science, 1998, 23, 1273.

22. Manivasagam, G.; Dhinasekaran, D.; Rajamanickam, A; Recent Patents on Corr. Sci., 2010, 2, 40.

23. Sun, L.; Berndt, C.C.; Gross, K.A.; Kucuk, A; J. Biomed. Mater. Res., 2001, 58, 570.

24. Surmenev, R. A; Surf.Coat Technol., 2012, 206, 2035.

25. Xu, S.; Long, J.; Sim, L.; Diong, C.H.; Ostrikov, K; Plasma, R.F; Proc. Polym., 2005, 2, 373.

26. Radin, S.; Duchane, P.; Christiansen, D; "Bioceramics" Butterworth-Heinemann Ltd., Oxford UK; 1993, 6, 59.

27. Borhane, H.F.; Olivier, G.; Pierre, W.; Daniel, C.; Pierre, L; Biomaterials., 2008, 29, 1177.

28. Meurice, E.; Leriche, A.; Hornez, J.C. Bouchart, F.; Rguiti, E.; Boilet, L.; Descampsa, M.; Cambier, F; J. Eur. Ceram. Soc., 2012, 32, 2673.

29. Wilson, R. M. Elliott, J. C.; Dowker, S. E. P; Am. Mineral., 1999, 84, 1406.

30. Boanini, E.; Gazzano, M.; Bigi, A; Acta. Biomater., 2010, 6, 1882.

31. Gopi, D.; Nithiya, S.; Shiny joy, E.; Kavitha, L; Spectro. Chim. Acta Part A., 2012, 92, 194.

32. Landi, E.; Sprio, S.; Sandri, M.; Tampieri, A.; Bertinetti, L.; Martra. G; J. Key. Eng. Mater., 2008, 361, 171.

33. Gasqueres, G.; Bonhomme, C.; Maquet, J.; Babonneau, F.; Hayakawa, S.; Kanaya. T; Magn. Reson. Chem., 2008, 46, 342.

34. Dahl, S.G.; Allain, P.; Marie, P.J.; Mauras, Y.; Boivin, G.; Ammann, P.; Tsouderos, Y.; Delmas, P.D.; Christiansen, C; Bone., 2001, 28, 446.

35. Ginty, F., Flynn, A.; Cashman. K.D; Br. J. Nutr., 1998, 79, 343.

36. Nakade, O.; Koyama, H.; Arai, J.; Ariji, H.; Takada, J.; Kaku, T.; Arch. Oral. Biol., 1999, 44, 89.

37. Farley, J.R.; Wergedal, J.E.; Baylink, D.J; Science., 1983, 222, 330.

38. Kim, S.R.; Lee, J.H.; Kim, Y.T.; Riu, D.H.; Jung, S.J.; Lee, Y.J.; Chung, S.C.; Kim, Y.H; Biomaterials., 2003, 24, 1389.

39. Wiesmann, H. P.; Plate, U.; Zierold, K.; Hohling H.J; J Dent Res., 1998, 77, 1654.

40. Schlesinger, P.H.; Blair, H. C.; Teitelbaum, S. L.; Edwards J.C; J. Biol. Chem., 1997, 272, 18636.

41. Neuman, W.F.; Neuman, M.W; University of Chicago press, Chicago, 1958.

42. Park, J.W.; Kim, Y.J.; Jang, J.H; Appl. Surf. Sci., 2011, 258, 977.

43. Eliaz N.: 'Degradation of implant materials', Springer Science \& Business Media, 2012

44. Sridhar, T.M.; Kamachi Mudali, U.; Subbaiyan, M; Corr. Sci., 2003, 45, 237.

45. Okazaki, Y.; Goth, E; Biomaterials., 2005, 26, 11.

46. Ma, L.R .; Sask, K.N .; Shi, C.; Brash, J.L.; Zhitomirsky. I; Mate. Lett., 2011, 65, 681.

47. Miller, P.D.; Holladay, J.W; Wear., 1958, 2, 133

48. Revie, R. W. (Eds); 'Uhlig's Corrosion Handbook', John Wiley \& Sons., 2011, 51, 133.

49. Lawrence, S.K.; Shults, G.M; J. Exp. Med., 1925, 42, 565.

50. Kohn. D.H; Curr. Opinion. Sol. State. Mater. Sci., 1998, 3, $302-$ 309.
51. Gonzalez, M.B.; Saidman, S; Corros. Sci., 2011, 53, 276.

52. Parsapour, A.; Khorasani, S.N.; Fathi, M.H; Sci. Technol., 2012, $28,125$.

53. Sridhar, T.M; Mater. Technol., 2010, 25, 184.

54. Dongxia, L.; Keith, S.; Matthew, Z.Y; Surf. \& Coat. Technol., 2011, 205, 3975 .

55. Bora M.; Cuneyt Tas, A; J. Am. Ceram. Soc., 2000, 83, 989-91.

56. Bozana, C.; Dejan, M; Vukoman, J; Dental. Journal., 2001, 58, 7.

57. Zhou-Cheng, W.; Yong-Jin, N.; Jin-Cong, H; Biomed. Sci. Eng., 2008, 1, 190 .

58. Prem Ananth, K.; Suganya, S.; Mangalaraj, D.; Ferreira, J.M.F.; Balamurugan A; Mater. Sci. and Engg. C., 2013, 33, 4160.

59. Singh, R.; Dahotre, N.B; J Mater Sci: Mater Med., 2007, 18, 725.

60. Kurella, A.; Dahotre. N. B; J. Biomater. Appl., 2005, 20, 5.

61. Kumar, S.; Narayanan, T.S.; Raman, G.S.; Seshadri, S.K; Mater. Sci. Eng. C., 2009, 29, 1942.

62. Seah, K.H.W.; Chen, X; J. Mater. Sci., 1993, 8, 1841.

63. Parsapour, A.; Khorasani, S.N.; Fathi, M.H.; J. Mater Sci and tech., 2012, 28, 125 .

64. Kannan, S.; Balamurugan, A.; Rajeswari, S; Electrochimica Acta., 2004, 49, 2395

65. Prabakaran, K.; Thamaraiselvi, T.V.; Rajeswari, S; Artif, T.B; Organs., 2006, 19, 84.

66. Parsapour, A.; Khorasani, S.N.; Fathi, M.H; Acta Metall. Sin. (Engl. Lett.)., 2013, 26, 409.

67. Martin, H.J.; Schulz, K.H.; Bumgardner, J. D.; Walters, K.B; Appl. Surf. Sci., 2008, 254, 4599.

68. Byrne, R.; Joner, M.; Kastrati, A; Minerva Cardioangiol. 2009, 57, 567.

69. Carlyle, W.C.; McClain, J.B.; Tzafriri, A.R.; Bailey, L.; Zani, B.G.; Markham P.M; J. Control Release., 2012, 162, 561-567

70. Hasebe, T.; Ishimaru, T.; Kamijo, A.; Yoshimoto, Y.; Yoshimura, T.; Yohena, S; Diamond Relat Mater., 2007, 16, 1343.

71. Wang, Y.; Liu, L.; Guo, S; Polym Degrad. Stab., 2010, 95, 207.

72. Weng, W.; Zhang, S.; Cheng, K.; Qu, H.; Du, P.; Shen, G.; Yuan, J.; Han, G;Surf. Coat. Tech., 2003, 167, 292.

73. Chen, Y.; Song, Y.; Zhang, S.; Li, J.; Zhao, C.; Zhang, X.X; Biomed Mater., 2011, 6, 025005 .

74. Xu, L.; Yamamoto, A; Coll. Surf B Biointerfaces., 2012, 93, 67.

75. Murat, A.; Tolga, K. S; Curr. Phy. Chem., 2012, 2, 224.

76. Subathira, A.; Meyyappan, R; Rec. Res. Sci. Tech., 2010, 2, 124.

77. Liu, A.; Oliveira, M.A.S; Mater. Sci., 2009, 27, 259.

78. Khan, W.; Kapoor, M.; Kumar, N; Acta Biomaterialia., 2007, 3, 541.

79. Madhan Kumar, A.; Nagarajan Suresh Ramakrishna, S. Sudhagar, P.; Yong Soo Kang Zuhair M. Gasem N.Rajendran, Hyongbum, K; Mater. Sci. Engg. C., 2014, 43, 76.

80. Ohtsuka, T; Inter.J. corr., 2012, 7, Article ID 915090.

81. Gopi, D.; Ramya, S.; Rajeswari, D.; Kavitha, L; Colloids. Surf. B. Bio Interface., 2013, 107, 130.

82. Hasanov, R.; Bilgic, S; Prog. Org. Coat., 2009, 64, 435.

83. Joseph, S.; McClure, J.C.; Sebastian, P.J.; J. Moreira, E.Valenzuela. J. Power Sources., 2008, 177, 161.

84. Hosseini, M.G.; Bagheri, R.; Najjar, R; J. Appl. Poly. Sci., 2011, 121, 3159.

85. Chen, F.; Liu, P; Appl. Mate. \& Inter., 2011, 3, 2694.

86. Hasanov, R.; Bilgic, S.; Gece, G; J. Sol. State Electro-Chem., 2011, 15, 1063.

87. Yeh, J.M.; Chin, C.P.; Chang, S; Mater. J. Appl. Poly. Sci., 2003, 88, 3624.

88. Armelin, E.; Pla, R.; Liesa, F.; Ramis, X.; Iribarren, J.I.; Aleman, C; Corr. Sci., 2008, 50, 721. 